\title{
Verdier og kryssende krav i barnehagen
}

\section{Lovverk og samfunnsmandat}

\begin{abstract}
Av Ingeborg TVeter Thoresen, f. 1943 tidl. rektor og førstelektor ved Høgskolen i Vestfold. E-post: ingeborg.t.thoresen@hbv.no
\end{abstract}

Barnehagens ansatte stilles overfor kryssende krav og må forholde seg til en rekke prinsipielle spørsmål. De springer ut av samfunnsmandatet, gitt i formålsparagrafen, og angår barnets og foreldrenes rettigheter, men også samfunnets plikter og ansvar.

I denne artikkelen tar jeg fram noen av forpliktelsene som myndighetene har påtatt seg ved å ratifisere internasjonale menneskerettsdokumenter som ble norsk lov med Menneskerettsloven i 2003. Det krever at både eiere, ansatte og foreldre må være bevisste på utfordringer som barnehagen dermed er forpliktet på.

Et nokså ferskt forskningsarbeid om arbeid med verdier i barnehagen, (Johansson 2015), viser at det de kaller verdipedagogikk, er et oversett område i barnehagen. Men barnas danning og oppdragelse skjer ikke i et «verditomt» eller «livssynsnøytralt» rom. Slike «rom» finnes ikke. Utfordringen er først å erkjenne det, dernest å få innsikt i og kunnskap om verdiene i barnehagen, og så komme til klarhet over hvordan verdier kommer til uttrykk. Personalet må arbeide bevisst med grunnleggende verdispørsmål, og med utfordringer som dette medfører. Det må de gjøre nettopp fordi denne delen av virksomheten angår vesentlige menneskerettslige bestemmelser.

\section{SAMFUNNSMANDATET OG DE GRUNNLEGGENDE VERDIENE}

Det er samfunnsmandatet, gitt av Stortinget i formålsparagrafen, ${ }^{1}$ som legitimerer både barnehagens virksomhet og barnehagelæreryrket. $^{2}$ Samfunnsmandatets sammensatte oppgave er å «ivareta barnas behov for omsorg og lek, og fremme læring og danning som grunnlag for barnets utvikling.» Det benevnes også som en «helhetlig tilnærming» $\mathrm{i}$ det pedagogiske arbeidet, og er karakterisert som en sosial-pedagogisk, nordisk barnehagetradisjon. I den nye stortingsmeldingen er aksenten flyttet, idet den helhetlige tilnærmingen av de sammensatte

1\$1. Formål: Barnehagen skal i samarbeid og forståelse med hjemmet ivareta barnas behov for omsorg og lek, og fremme læring og danning som grunnlag for allsidig utvikling. Barnehagen skal bygge på grunnleggende verdier i kristen og humanistisk arv og tradisjon, slik som respekt for menneskeverdet og naturen, på åndsfrihet, nestekjærlighet, tilgivelse, likeverd og solidaritet, verdier som kommer til uttrykk i ulike religioner og livssyn og som er forankret i menneskerettighetene.

2 Den nye formålsparagrafen ble virksom fra 2010, etter en omfattende prosess. Bostad-utvalget fikk i oppdrag å komme med forslag til ny formålsparagraf for både barnehage og opplæring. Formål for framtida. (Bostad, 2007). Den nye formålsparagrafen måtte ivareta unntaksbestemmelsen i fjerde ledd i den gamle. Derfor trådte formålsparagrafen i kraft først i 2010. LOV-200506-17-64. Endret ved lov 19 des 2008 nr. 119 (ikr. 1 aug 2010 iflg. res. 18 juni 2010 nr. 828). 
oppgavene ses i lys av læring. ${ }^{3}$

Formålsparagrafen klargjør verdiene som alle barnehager både skal bygge på og virkeliggjøre. Private barnehager og menighetsbarnehager kan ha annen verdiforankring og særlige bestemmelser om livssynsformål, ${ }^{4}$ men verdiene er de samme for alle barnehager. Det er primært disse verdiene jeg fokuserer på i det følgende.

Formålsparagrafen benevner verdiene som «grunnleggende verdier i kristen og humanistisk arv og tradisjon», og er også «verdier som kommer til uttrykk i ulike religioner og livssyn og som er forankret i menneskerettighetene». Slik ivaretar Stortinget den arv og tradisjon som samfunnet bygger på (jfr. grunnlovsendringen i 2008), samtidig som lovteksten gir verdiene en bred forankring i tråd med mangfoldet i samfunnet, når det gjelder religion og livssyn. Verdiene forankres også i menneskerettighetene.

\section{VERDIER I BARNEHAGEN}

Barnehagen er en stor og viktig samfunnssektor. Et forskermiljø ved Universitetet i Stavanger har vært opptatt av hva slags verdier som blir kommunisert i barnehagen. De har interessant nok funnet at «verdipedagogikk», som de kaller det, er et oversett område i barnehagen (Johansson, 2015). Det er en viktig observasjon. Men det er ikke bare i barnehagen at dens verdier og verdiforankring over- ses. I den nylig framlagte stortingsmeldingen legger departementet premisser for ny rammeplan. Det blir ifølge meldingen en endring som er større enn en revisjon av eksisterende rammeplan (Kunnskapsdepartementet, 2016). Når endringene $\mathrm{i}$ den forrige formålsparagrafen omtales, er endringene i verdier og verdigrunnlag, som Stortinget ble enige om, knapt omtalt og slett ikke utdypet. Ifølge meldingen besto endringen $\mathrm{i}$ loven $\mathrm{i}$ at danning erstatter oppdragelse (Kunnskapsdepartementet, 2016:24). Men ifølge forarbeidene omfatter danning oppdragelse (Kunnskapsdepartementet, 2007:28). ${ }^{5}$ Og oppdragelse som pedagogisk anliggende kommer barnehagelærerne ikke unna. Både den funksjonelle og intensjonale oppdragelsen er til stede i hverdagslivets praksis.

Det er, slik jeg ser det, oppsiktsvekkende at departementet overser verdidimensjonen i barnehageloven, for tausheten tilslører vesentlige utfordringer, både pedagogiske og menneskerettslige, for barnehagens personale. Det er utfordringer som nettopp verdier og verdiforankring representerer i barnehagens og samfunnets religiøse og kulturelle mangfold.

Forskergruppen ved Universitetet i Stavanger erfarer at dette feltet også er utfordrende. De har sett at barnehagelærere mangler språk for verdier. ${ }^{6}$ Det bøter de på, ikke med å framholde de verdiene som barnehage-

3 «Barnehagetilbudet skal fortsatt bygge på den nordiske tradisjonen med et helhetlig læringssyn og en integrert barnehage for alle under skolepliktig alder» (Kunnskapsdepartementet, 2016:8).

4 Formålsparagrafen fra 1983 hadde en formulering som krevde fritak. "Barnehagen skal hjelpe til med å gi barna en oppdragelse i samsvar med kristne grunnverdier". Loven hadde fritak i fjerde ledd. Fritaket måtte videreføres etter revisjon av formålsparagrafen i 2008. Lovarbeidet tok et par år. Tillegget $\ 1$ a «Særlige formål» ble vedtatt i 2010. Det lyder: «Eiere av private barnehager kan i vedtektene bestemme at verdiene i loven $\$ 1$ ikke skal forankres i den kristne og humanistiske arv og tradisjon. Private barnehager og barnehager eiet eller drevet av menigheter innen Den norske kirke kan i vedtektene fastsette særlige bestemmelser om tros- eller livssynsformål.»

5 «Departementet støtter utvalget i denne vurderingen og mener at begrepet «danning» også dekker «oppdragelse». Etter departementets mening er det derfor ikke nødvendig å presisere oppdragelse i tillegg til danning i formålsbestemmelsen.» https://www.regjeringen.no/contentassets/0869892c0fd44cf298cc33b90cac7b94/no/pdfs/otp200720080047000dddpdfs. pdf

6 Med en svensk forsker R. Thornberg definerer de verdipedagogikk som «den praksisen der voksne har et ansvar for at barn skal utvikle forståelse for ulike verdier og ulike typer verdikonflikter». (Johansson, 2015:16) 
loven har fastsatt som grunnlag for virksomheten, men ved å definere en rekke verdier som de knytter til ulike «verdifelt». ${ }^{7}$ Ved dette valget kan de analysere hvilke verdier som barnehagen selv legger vekt på, og som forskerne ser kommer til uttrykk i barnehagens hverdag (Johansson, 2015:40).

Det er fortjenstfullt at de setter verdier på dagsorden. Men det bidrar ikke til å heve barnehagelæreres bevissthet om samfunnsmandatets verdier i formålsparagrafen som grunnlag og ledestjerne for virksomheten.

For meg er selve begrepet «verdipedagogikk» dessuten en tautologi, idet all pedagogikk innebærer verdier og verdivalg. Pedagogikk er et normativt fag både i teori og praksis. Nettopp derfor er det behov for å bevisstgjøre personalet på pedagogikkens normative karakter, og bidra til å samtale om verdienes betydning i hverdagen. Det er et anliggende der Stavangerforskerne og jeg har et felles engasjement.

\section{VERDIER OG FORANKRING}

Mitt utgangspunkt er at barnehagelærere på den ene siden trenger å bli bevisste på samfunnsmandatets verdier, og i dette arbeidet være klar over spenningene som finnes i det, mens de, på den andre siden, skal ivareta forpliktelsene som de er pålagt $i$ lys av menneskerettighetene. Utfordringen, å se barnehagen som en samfunnsinstitusjon, betyr derfor oppmerksomhet på barnehagens grunnleggende verdier og hvordan de virkeliggjøres gjennom danning og oppdragelse, omsorg, lek og læring, samtidig som menneskerettslige bestemmelser som angår barn, foreldre og samfunn, ivaretas.
Verdier er ikke begreper som kommer rekende på ei fjøl. De er uttrykt og formidlet gjennom årtusener $\mathrm{i}$ ulike filosofiske byggverk, religiøse skrifter og tradisjoner. Det kan benevnes forankring. Samtidig får verdiene ulike uttrykk i ulike sammenhenger og til ulike tider. Tross sin forankring er verdier både faste og grunnlag for forhandlinger. Menneskeverd er et eksempel. Samfunnet legger til grunn at ethvert menneske har et iboende verd, slik det står i FNs Verdenserklæring om menneskets rettigheter. ${ }^{8}$ Hvordan det ivaretas, er gjenstand for diskusjon og forhandlinger. Slik er verdiene absolutte på formuleringsarenaen, men også relative i den praktisk-politiske hverdagen. Historien viser at samfunnets syn på ulike forhold er endret. Det gjelder for eksempel slaveriet, kvinner og barn, likeverd og likestilling, og samfunnssystemer som Apartheid, der nettopp kravene om menneskeverd og rettferdighet har vært noe av drivkraften i en etisk og politisk kamp mot urett.

I et samfunn der én religion eller livsanskuelse har hatt eller har hegemoniet, kan verdiene i samfunnet lett ses som ens «egne verdier», tilhørende sin tradisjon. Men ettersom samfunnets mangfold øker, utfordres både myndighetene, fellesskapet og enhver, gjennom kunnskapsinnhenting og dialog, til å undersøke hva som er felles og forskjellig, og finne fram til verdier som en kan enes om, selv om verdier uttrykkes gjennom kulturelt bestemte normer og regler, som det er uenighet om. Debatten om hijab er et aktuelt eksempel, der spørsmålet om hijab både ses som et symbol på religionsfrihet, som skal respekteres, og på kvinneundertrykkelse, som skal bekjempes.

\footnotetext{
7 Verdifeltene benevnes som etiske verdifelt, demokratiske verdifelt, disiplinerende verdifelt, effektivitetsverdier og kompetanseverdier.

8 http://www.fn.no/FN-informasjon/Avtaler/Menneskerettigheter/FNs-verdenserklaering-om-menneskerettigheter
} 
«Verdier udtrykker noget, der gør sig greldende i samfundet; de kan derfor ikke isoleres fra det konfliktfylte politiske felt. Det gcelder også - og måske i scerlig grad - for peedagogiske verdier (...) Et bud på peedagogiske verdier vil alltid vere et bud på, hvordan samfundet skal se ud i fremtiden»

Sitatet et hentet fra en liten og viktig bok om pedagogiske og politiske verdier (Vase Frandsen, 2008). Der peker forskerne videre på at $\mathrm{i}$ og med at barnet er avhengig av sine omgivelser for å tilegne seg kunnskap og ferdigheter, og for å bli selvstendig, ${ }^{9}$ er oppdragelse en gitt oppgave, og pedagogiske verdier som skal orientere oppdragelsen, et samfunnsmessig anliggende. Oppdragelse fungerer i et praksisfelt, i samfunnsinstitusjoner, som er politisk definert, men som har en relativ autonomi. Det innebærer at «der eksisterer et spændingsforhold mellem pædagogiske og politiske værdier» (op.cit.:17).

Barnehage og skole er viktige institusjoner for formidling av verdier som skal holde samfunnet sammen (Thoresen, 2003). Ethvert samfunn er avhengig av en viss oppslutning om felles verdier. Det var også et viktig anliggende i forarbeidene til revisjon av formålsparagrafene for barnehage og opplæring.

Forarbeidene i utredningen Formål for framtida (Bostad, 2007) og drøftinger $\mathrm{i}$ Stortinget, under revisjon av formålsparagrafene, viser også hvor utfordrende det var å komme fram til verdier som man kunne enes om. Også Stortinget var opptatt av enighet $i$ en så viktig samfunnssak. Dermed ble verdiene i de offentlige barnehagene forankret både $\mathrm{i}$ «kristen og humanistisk arv og tradisjon», i «ulike religioner og livssyn» og $\mathrm{i}$ «menneskerettighetene». Med andre ord ble verdiene gitt en meget åpen verdiforankring. Det har gitt grunnlag for akademiske diskusjoner (Andreassen, 2014). Det er imidlertid ikke denne artikkelens hovedanliggende. I den endelige lovteksten ble verdienes forankring i majoritetens verditradisjon flyttet fram. Fordi offentlige barnehager favner vidt, måtte teksten ha formuleringer som både majoritet og minoriteter kan kjenne seg ivaretatt ved. Rammeplanen motiverer dette valget slik:

I Norge har den kristne og humanistiske tradisjon hatt historisk og kulturell innvirkning på samfunnsutviklingen. Kristen og humanistisk som begrepspar understreker at dette er retninger som historisk både har utfylt og korrigert hverandre. Norge er blitt et flerkulturelt samfunn, der religiøst mangfold blir stadig mer tydelig. Ved à synliggjøre religioner og livssyn i formålet, anerkjennes både at religioner og livssyn har en plass i det offentlige rom og at det er plass for en åndelig dimensjon $i$ barnehagen. En slik plass må brukes som utgangspunkt for dialog, åndsfrihet og respekt for mangfold, ikke for å uttrykke et religiøst eller verdimessig hegemoni. Skal barnehagens verdigrunnlag kunne ha legitimitet for alle som likeverdige individer, må det vere mulig for barn, foreldre og ansatte med ulik religiøs og livssynsmessig tilhørighet å slutte seg til verdigrunnlaget (Kunnskapsdepartementet, 2011:10-11).

Det er en påminnelse om hvilke åndsstrømninger som har vært med på å forme tenkesett og verdier $\mathrm{i}$ vårt samfunn gjennom århundrer, uten at det skal «uttrykke et religiøst eller verdimessig hegemoni». Det skal være retningsgivende for barnehagen.

Arbeidet med verdier og verdigrunnlag krever dialog de ansatte imellom. En rekke

9 Dette kalles «det pedagogiske paradoks» i faglitteraturen (Oettingen, 2001) 
spørsmål kan være utgangspunkt for samtale om hva som menes med kristen-humanistisk arv og tradisjon, og hvordan det skal komme til uttrykk i barnehagens hverdag og innhold. Men man må også drøfte hvilke religiøse eller livssynsmessige tradisjoner som den enkelte barnehage bør legge vekt på. En finner både retningslinjer og begrunnelse i rammeplanens innledning og under fagområdet «Etikk, religion og filosofi».

Barnehagens personale må trene på å samtale om dette, både å lytte til andre, og delta i barnehagens arbeid med å formulere individuelle og kollektive standpunkt og begrunnelser, på faglig vis. Personalmøter må være øvelses-steder slik at de ansatte med trygghet kan gå i dialog med foreldre i møter preget av åpenhet og tillit. For foreldre må kunne forvente høy grad av bevissthet, kunnskap og klokskap på livssynsområdet. Når personalet er forberedt og gode forbilder på dette feltet, har det betydning for toleranse som skal praktiseres, og læres nettopp gjennom hverdagslivet.

FORMÅLSPARAGRAFENS VERDIER OG BARNEHAGENS OPPGAVER

Som lovteksten viser, har barnehagen fått et «skal»-oppdrag. ${ }^{10}$ Det gjelder både oppgaver og verdier. Barn dannes i vekselvirkning med den verden de møter. Barnehagen er en viktig del av barnas verden, der ikke minst samspillet med personalet har en avgjørende rolle. Barnehagens ansatte formidler verdier gjennom sin væremåte, gjennom den pedagogiske virksomhetens innhold og hvordan hele hverdagslivet innrettes. Alle ansatte i barnehagen er bærere av verdier. Valg av omgangsformer, regler, arbeidsformer og lærestoff er uttrykk for verdivalg. Verdier, etikk og pedagogikk kan ikke skilles ad.

Det dreier seg om hvordan barnets menneskeverd ivaretas i omsorgsarbeidet, oppdragelsen og danningen, og i barnas lek. Både ordene og stemmen de ansatte bruker har betydning, likeså grensene de voksne setter, og sanksjonene de bruker overfor barna. I respekt for det enkelte barn må den voksne være seg bevisst sin rolle når det gjelder ikke å blande seg i leken (jfr. Margaretha Rønneberg 2016), ${ }^{11}$ eller når det gjelder å gå inn i konflikter. Balansen mellom aktiv inngripen og tilbakeholdenhet krever refleksjon og skjønnsutøvelse. Barn skal lære respekt for naturen og livsmiljøet. Solidaritet er et utfordrende begrep, både etisk og politisk (Løgstrup, 1996). Kan solidaritet praktiseres og læres i barnehagen med tanke på barnas sosiale kompetanse? Nestekjærlighet er en nærliggende verdi, en impuls til praktisk handling. Kjærlighet er kommet på den pedagogiske dagsorden (Melvold \& Øverenget, 2015). Utøvelse av nestekjærlighet - at voksne bryr seg - og spesielt om den som trenger ekstra omsorg, har betydning for barnas erfaring med nestekjærlighet. Det vil være et vern om menneskeverd og en motvekt mot mobbing og utstøting. Tilgivelse er også en av verdiene som skal levendegjøres. Tilgivelse som en ny start, er viktig i forholdet mellom små og store (Glaser, 2011), ikke som et krav, men som en gave. I en barnehage med barn fra ulike hjem, med foreldre med ulik tro og livssyn, er åndsfrihet og toleranse begreper med praktisk betydning. Det er ikke så ofte slike begreper brukes. Men for barnehagen må det være et mål å skape et miljø som legger vekt på åpenhet

10 Ifølge tidligere stortingspresident Kirsti Kolle Grøndahl brukes ordet skal sjelden i lovtekster. Men når det brukes, er det desto viktigere å være oppmerksom på det. (I samtale i Drammen 20. jan. 2016).

11 http://barnisten.blogspot.no/2015/11/adultonormativitet-11-tron-att-barn.html 
og tillit, med raushet og respekt for forskjellighet.

Spørsmålene om verdier aktualiseres tydeligst i møte mellom mennesker, og når oppgavene i barnehagen løses i hverdagslivet. Noen av oppgavene angår på en særlig måte forholdet og ansvarsfordelingen mellom foreldre og barnehage, hjem og stat, fordi oppdragelse og undervisning berører foreldrenes primære ansvar og religionsfriheten.

\section{BARNEHAGEN OG FORELDRENE. FORPLIKTELSER OG RETTIGHETER}

Fordi barna er i barnehagen store deler av deres våkne tid og fra de er ganske små, er forholdet mellom foreldre og barnehage og foreldresamarbeid av grunnleggende betydning. At foreldrene har hovedansvaret for barnets oppdragelse, er noe vi tar for gitt i vårt samfunn. Det har imidlertid vært nødvendig å uttrykke eksplisitt i en rekke menneskerettighetsdokumenter, ikke minst av historiske grunner. Forholdet mellom stat og familie ble i nyere tid aktualisert gjennom erfaring med totalitære regimer under og etter andre verdenskrig. Forholdet fikk derfor en egen artikkel i FNs verdenserklcering om menneskerettigheter $i$ 1948: «Familien er den naturlige og grunnleggende enhet i samfunnet og har krav på samfunnets og statens beskyttelse» (artikkel 16, 3. ledd). Det gjentas i FNs internasjonale konvensjoner om økonomiske, sosiale og kulturelle rettigheter, artikkel 10, og i FNs internasjonale konvensjoner om sivile og politiske rettigheter, artikkel 23, 1. ledd. ${ }^{12}$
Familiens stilling i samfunnet ble sett som «naturlig» og «grunnleggende», i 1948 . Familien er fortsatt samfunnets grunncelle uansett familie-former. «Enhver har rett til respekt for sitt privatliv og familieliv, sitt hjem og sin korrespondanse» (Den europeiske menneskerettighetskonvensjonen, artikkel 8, 1. ledd). I Verdenserklæringen heter det videre: «Foreldre har fortrinnsrett til å bestemme hva slags undervisning deres barn skal få», artikkel 26, 3. ledd. ${ }^{13}$ FNs internasjonale konvensjoner om økonomiske, sosiale og kulturelle rettigheter, artikkel 10, gjentar at familien er den naturlige og grunnleggende samfunnsenhet som det må ytes vern om og bistand til, fordi den er ansvarlig for omsorg for barnet. Støtten til barnet, uansett bakgrunn, framholdes også i FNs internasjonale konvensjoner om sivile og politiske rettigheter, 24, 1. ledd.

FNs barnekonvensjon av 1989 brakte imidlertid inn et fornyet engasjement for barnets rettigheter i vår tid. ${ }^{14}$ Konvensjonen ble vedtatt og ratifisert av nesten alle land, med unntak av Somalia og USA. Den ble inkorporert $\mathrm{i}$ norsk lov med Menneskerettsloven i 2003 og gjelder barn fra 0 til 18 år. I FNs barnekonvensjon er artikkel tre sentral, med bestemmelsen om barnets beste.

Barnets rett og foreldrenes plikter, ansvar og rett henger nøye sammen. Når det er tale om barnets rett, vedrører det som regel også foreldrenes ansvar, plikter og rettigheter.

Artikkel 3. «Partene skal bestrebe seg på å sikre anerkjennelse av prinsippet om at begge foreldre har et felles ansvar for barnets oppdragelse og utvikling. Foreldre, eventuelt verger, har hovedansvaret for barnets

12 Se forøvrig Menneskerettsloven i www.lovdata.no.

13 Konvensjonens originaltekst på engelsk der begrepet er education er et videre begrep enn undervisning. Det er vekselsvis oversatt med oppdragelse og undervisning.

14 Konvensjonen hadde sine forløpere. Allerede i 1924 vedtok Folkeforbundet «Declaration of the right of the child», (The 1924 Declaration of Geneva). Det var den første menneskerettserklæring vedtatt av en internasjonal organisasjon noensinne (Høstmælingen, Sandberg, \& Kjørholt, 2008) 
oppdragelse og utvikling. Barnets beste skal for dem komme i første rekke.

Artikkel 18. For å garantere og fremme de rettigheter som er fastsatt $i$ denne konvensjon, skal partene yte egnet bistand til foreldre og verger når de utfører sine plikter som barneoppdragere, og de skal sørge for utvikling av institusjoner, ordninger og tjenester innen barneomsorg.

Staten har ansvar for å støtte foreldrene i deres omsorgs- og oppdragelsesoppgaver. På den ene siden er barnehagen et svar på disse forpliktelsene, og på den andre siden er barnehagen forpliktet på konvensjonens bestemmelser. Nettopp fordi foreldre overlater ansvaret for barna til barnehagen, har samfunnet stor innflytelse på barnas liv, deres danning og oppdragelse. Imidlertid har staten også et ansvar for å beskytte barnet dersom barnets foreldre svikter sine oppgaver, eller misbruker sin foreldrerolle (se artikkel 9, 1. ledd).

Forenklet oppsummert har foreldre og barn rettigheter, mens samfunnet har plikter. Lovgiverne regulerer ansvarsforholdet mellom familien og det offentliges omsorgsordninger med følgende tekst: «Barnehagen skal i samarbeid og forståelse med hjemmet ...» . Dette påbud har, slik det er vist, sitt feste i ovennevnte bestemmelser.

Barnets rett til medvirkning er et prinsipp i barnekonvensjonens artikkel $12 .{ }^{15}$ Som en følge av det kom barnets rett til medvirkning inn i barnehageloven i 2006:

\section{\$ 3. Barns rett til medvirkning}

Barn i barnehagen har rett til å gi uttrykk for sitt syn på barnehagens daglige virksomhet. Barn skal jevnlig få mulighet til aktiv deltakelse i planlegging og vurdering av barnehagens virksomhet.

Barnets synspunkter skal tillegges vekt $i$ samsvar med dets alder og modenhet.

(Lov om barnehager)

Det er et anliggende som har fått stor oppmerksomhet i barnehagens faglitteratur og praksis (Østrem et al., 2009). Til grunn for bestemmelsen om barns medvirkning ligger synet på barnets menneskeverd og respekt for barnet i dets egen rett.

Spørsmålet som både barnehagens ansatte og foreldre må stille, er om alle barn blir møttmed respekt og likeverd. Barn har rett til respekt (Korczak, 2016). Respekt har med retten til å bli hørt, lyttet til og har med medvirkning å gjøre. Forskning viser imidlertid at sosiale forskjeller spiller en rolle for barnehagelæreres væremåte overfor de ulike barna (Foss, 2009; Lindskov, 2005; Palludan, 2005). Men også barnas væremåte synes å virke inn på barnehagelærerens forhold til barnet. Danske Charlotte Palludan avdekker interessante sammenhenger i sin forskning, der hun viser at «Børnehaven gør en forskel», i strid med intensjonene om å nedbygge forskjeller (Palludan, 2005). Bevisstheten må økes om den betydning som den voksnes væremåte har i møte med barn generelt (Foss, 2009, 2013), og spesielt i møte med et barn som «alltid» maser, som «aldri» sitter stille når det er forventet, som ofte er del av konflikter, eller er en som «aldri» tar initiativ, som gir seg der andre går på. Her vil bevisst arbeid om samspillet mellom voksne og barn bidra

15 Partene skal garantere et barn som er $i$ stand til å danne seg egne synspunkter, retten til fritt å gi uttrykk for disse synspunkter $i$ alle forhold som vedrører barnet, og tillegge barnets synspunkter behørig vekt $i$ samsvar med dets alder og modenhet. 
til mestring og et bedre hverdagsliv. Det viser det danske forskningsprosjektet «Barnet i centrum» (Broström, Hansen, \& Svinth, 2016). Dessverre viser nyere forskning fra blant annet Universitetet i Agder at ikke alle barn har det bra i barnehagen, jamfør prosjektet «Hele barnet. Hele løpet. Mobbing i barnehagen» (Lund et al., 2015). ${ }^{16}$ Mobbing er en utfordring som barnehagene må ta fatt i for barnas skyld, men også ut fra oppgavene og verdiene som barnehagen er satt til å realisere.

\section{INNHOLDET}

Først i 2006, hele ti år etter den første nasjonale rammeplanen fra 1996, fikk barnehageloven en egen paragraf om barnehagens innhold.

\section{$\$$ 2. Barnehagens innhold}

Barnehagen skal vere en pedagogisk virksomhet.

Barnehagen skal gi barn muligheter for lek, livsutfoldelse og meningsfylte opplevelser og aktiviteter.

Barnehagen skal ta hensyn til barnas alder, funksjonsnivå, kjønn, sosiale, etniske og kulturelle bakgrunn, herunder samiske barns språk og kultur.

Barnehagen skal formidle verdier og kultur, gi rom for barns egen kulturskaping og bidra til at alle barn fär oppleve glede og mestring $i$ et sosialt og kulturelt fellesskap.

Barnehagen skal støtte barns nysgjerrighet, kreativitet og vitebegjer og gi utfordringer med utgangspunkt $i$ barnets interesser, kunnskaper og ferdigheter.

(Lov om barnehager)

Etter i første ledd å ha definert barnehagen som en pedagogisk virksomhet, settes bar- net i fokus i de neste leddene. Men som jeg peker på nedenfor, angår de også foreldrene. Innholdet er konkretisert i rammeplanen, blant annet med sju fagområder, der «Etikk, religion og filosofi» er ett av disse. Alle barnehager er forpliktet til å ivareta alle fagområdene, uansett forankring. I en evaluering fra 2009 der implementering av rammeplanen som kom i 2006, var tema, viser omfanget av barnehagens arbeid med fagområdene store ulikheter.

Fagområdet «Kommunikasjon, språk og tekst» står fram som fagområdet som det $\mathrm{i}$ særklasse arbeides mest med, ${ }^{17}$ mens bare 15 $\%$ arbeider ganske mye med «Etikk, religion og filosofi» (Østrem et al., 2009:25). Ifølge forskerne er det vanskelig å forklare de store forskjellene, i og med at fagområdene generelt omtales som likeverdige i rammeplanen. De tilskriver det «andre føringer» eller «intern fagkultur og tradisjon» (op.cit.:25). Det er tankevekkende at «Etikk, religion og filosofi» var det fagområdet som «har lavest prioritet» og «kommer på en solid sisteplass» (Østrem et al., 2009:26). Det samsvarer imidlertid med Stavangerforskernes funn (Johansson, 2015). ${ }^{18}$

Å arbeide med fagområdet «Etikk, Religion og filosofi» er nødvendig for å ivareta både barnets rett og samfunnets forpliktelser. Det er verd å diskutere hva det kan komme av at verdier er oversett, og mangler språk blant barnehagens ansatte? Jeg tror det kan ha sammenheng med at forbindelsen mellom verdiene og verdiforankringen i barnehageloven og rammeplanen ikke vies tilstrekkelig oppmerksomhet i utdanning og etterutdanning. Som nevnt gir heller ikke Stortingsmeldingen

$16 \mathrm{http}: / /$ www.uia.no/forskning/teft/teft-artikler/ikkje-berre-kos-i-barnehagen

17 I følge tabell 8 er det $71 \%$ som arbeider i stor grad med dette kunnskapsområdet.

18 Selv om formålsparagrafene i 2005 og 2010 er forskjellige, er det en viss kontinuitet i verdier og verdiforankring, og «Formålet er retningsgivende for øvrige lovbestemmelser og styringsdokumenter for barnehagen og fungerer som mandat for alle som har et ansvar for virksomheten». (Kunnskapsdepartementet, 2016:24) 
Tid for lek og lcering: Bedre innhold i barnehagen (Kunnskapsdepartementet 2016) hjelp til styrket arbeid med verdier, når verken kvalitet eller barnehagens tradisjonelle, helhetlige pedagogikk forklares eller ses i forhold til de overordnede perspektiver i formålsparagrafen.

\section{INNHOLDET OG AKTUELLE DILEMMAER}

Religion og livssyn kommer altså inn i den pedagogiske virksomheten på flere vis. Først med verdiene, som angår oppgavene personalet er pålagt. De er løftet fram ovenfor. Men utfordringene gjelder også barnehagens innhold, og spesielt fagområdet «Etikk, religion og filosofi». Her aktiveres dilemmaer knyttet til forholdet mellom foreldres rettigheter når det gjelder barnets oppdragelse og religionsfrihet, barnets rettigheter, og samfunnets behov og ønsker (se også Thoresen og Winje 2013).

Det pedagogiske personalet må kjenne rettighetene som både barn og foreldre har på oppdragelsens og danningens område, som spesielt angår tro, livssyn, religionsfrihet og ikke-diskriminering. Barnehagen forvalter plikter og ansvar på myndighetenes vegne.

Derfor trenger personalet innsikt i forhold som representerer motstridende interesser, barnets, foreldrenes og samfunnets, jfr. rammeplanen, der det heter: "Personalet må arbeide for å finne balanse mellom respekt for foreldrenes prioriteringer og å ivareta barns rettigheter og grunnleggende fellesverdier som barnehagen er forpliktet på," (Kunnskapsdepartementet, 2011:20).

Når det kommer til barnets rettigheter, skal konvensjoner og lover gi barn beskyttelse, og eget rom for utfoldelse som selvsten- dige individer, ikke bare som medlemmer i en familie eller et fellesskap. De juridiske bestemmelsene omhandler statens forpliktelse til vern om og beskyttelse av individet på basis av dets rettigheter. De ansatte har et mandat og en funksjon på samfunnets vegne. Barnet lever i relasjoner og er prisgitt disse, både i hjemmet og i barnehagen. Bestemmelsene i både konvensjoner, lov og forskrifter søker å regulere relasjonene. Et overordnet og ledende prinsipp er «barnets beste». Imidlertid er det i konkrete situasjoner at de ledende prinsippene skal anvendes.

Barnehagefolk ser kan hende på rammeplanen først og fremst som en pedagogisk veileder. Ikke desto mindre er både barnehageloven og rammeplanen juridiske dokumenter med både juridiske, pedagogiske og etiske implikasjoner. Og nettopp der er det at barnehagelæreren skal anvende sin kunnskap og sitt pedagogiske og etiske skjønn. For dilemmaene kan ikke løses teoretisk. ${ }^{19}$ Teoretisk kunnskap skal hjelpe en yrkesutøver til å avklare motstridende hensyn og interesser. Men det er i praksis, ut fra kunnskap, faglig og etisk skjønn og med klokskap, at en barnehagelærer må håndtere slike dilemmaer. For $\ll$ Barnehagens verdiformidling skal praktiseres i overensstemmelse med menneskerettskonvensjoner som Norge er bundet av» (Kunnskapsdepartementet, 2011:12).

De ansatte må ta hensyn til «barnas alder og det enkelte hjems kulturelle, religiøse og verdimessige tilknytning». Foreldrene og ansatte må komme fram til en felles forståelse av barnehagens oppgaver og hva som er foreldrenes hele og fulle ansvar, og må unngå lojalitetskonflikter for barna. Barnehagen skal lære barna om blant annet verdier forankret i kristen og humanistisk arv og tradisjon, men

19 Dette synspunktet har jeg drøftet med juridiske spesialister i menneskerettsspørsmål, med spesiell innsikt i religionsfrihet og foreldrerett, i samtale den 2. juli 2012. 
opplæring til tro er hjemmets ansvar (op.cit.). Men foreldre kan heller ikke gå inn i arbeidet overfor pedagogen med krav om å styre deler av den pedagogiske virksomheten. Derfor er informasjon, og kommunikasjon på dette feltet vesentlig. Da trengs språk. Som Stavangerforskerne etterlyser.

Barnets rettigheter $\mathrm{i}$ forhold til religion synes å være et tema som er lite aktuelt i pedagogisk faglitteratur og dermed et uutforsket område. Imidlertid leverte juristen Julia Köhler-Olsen en avhandling om Barnets rett til selvbestemmelse i forhold til religiøse normer for den juridiske doktorgrad i 2012 (KöhlerOlsen, 2012).

Med barnehageloven og rammeplan for barnehagen har myndighetene, slik jeg ser det, pekt på at barn er selvstendige individer. De lever også i et samfunn med religiøst og kulturelt mangfold. Det har konsekvenser for barnehagen som samfunnsinstitusjon. Slik sett gir barnehagen en annen ramme enn hjemmet. Rammeplanen uttrykker at barn har «rett til å bli kjent med samfunnet det vokser opp i». Samtidig minner den om beskyttelse mot religiøs og kulturell diskriminering. Barn skal anerkjennes og vises respekt nettopp med den ballast de har hjemmefra, og den tilknytning de bringer med seg i barnehagen mht. livssyn.

Dette ivaretas, på prinsipiell basis, i formålsparagrafen, men også i rammeplanens innledning og gjennom fagområdet «Etikk, religion og filosofi», slik det presenteres der. Barnets kunnskap skal utvides i barnehagen. Det er en god begrunnelse for arbeidet med fagområdet «Etikk, religion og filosofi».

I det pedagogiske arbeidet skal personalet undre seg sammen med barna om etiske, reli- giøse og livsfilosofiske spørsmål, og barn skal møte religion som sosiale og kulturelle konkrete foreteelser i hverdagslivet, også høytidstradisjonene, som en del av rammeplanens innhold. ${ }^{20}$

Det spenningsfylte for de ansatte ligger i de motforestillinger barnehageansatte kan møte hos foreldre som vil framholde sitt primære ansvar for den livssynsmessige oppdragelsen. De må selvsagt innrømmes sitt primære ansvar, men barnehagens kryssende krav må også tydeliggjøres for dem, blant annet barnets rett til å bli kjent med det samfunn det vokser opp i. Utfordringene ligger både i dialogen med foreldrene og tilretteleggingen for barna.

Som på andre av barnehagens områder dreier det seg om å utøve sin faglighet i åpenhet og tillit med pedagogisk og etisk skjønn «i samarbeid og forståelse med hjemmet».

Med formålsparagrafen og fagområdet «Etikk, religion og filosofi» trenger barnehagens personale kunnskaper om verdiene og verdienes forankring, men også om hvordan de skal arbeide med fagområdet. Hver enkelt barnehage har sine spesielle utfordringer ut fra sammensetningen av både ansatte, barn og foreldre. Derfor har ikke artikkelen gitt oppskrifter, men ønsket å øke bevisstheten hos barnehagens ansvarlige om ansvaret også på dette feltet. Framfor alt dreier det seg om hvordan barnehagens ansatte, i møtet med barn og foreldre, virkeliggjør barnehagens verdier gjennom oppgavene som de løser i hverdagslivet.

\section{LITTERATUR}

Andreassen, B.-O. (2014). Religionslæreren - en rolle i endring. Norsk Pedagogisk

20 Se for øvrig Rammeplan for barnehagens innhold og oppgaver, 2011, avsnitt 3.5, «Etikk, religion og filosofi»s. 45-46. Der er det redegjort for hva barnehagen skal bidra med på dette området, og hvilke krav som settes til personalet. 
Tidsskrift, 98(05), 316-328.

Bostad, I. (2007). Formål for framtida: formål for barnehagen og oppleringen : utredning fra et utvalg oppnevnt ved kongelig resolusjon 2 . juni 2006, avgitt til Kunnskapsdepartementet 8. juni 2007. Oslo: Departementenes servicesenter, Informasjonsforvaltning.

Broström, S., Hansen, O.H., \& Svinth, L. (2016). Barnet i centrum : pcedagogik og relationer i vuggestue og dagpleje. København: Akademisk Forlag.

Foss, E. (2009). Den omsorgsfulle veremåte: en studie av voksnes veremåte i forhold til barn $i$ barnehagen. Institutt for utdanning og helse, Det psykologiske fakultet, Universitetet i Bergen.

Foss, E. (2013). Omsorgsutøving og etikk, s. 78-103. Oslo: Gyldendal Akademisk.

Glaser, V. (2011). Barnehagens grunnsteiner: formålet med barnehagen. Oslo: Universitetsforlaget.

Høstmælingen, N., Sandberg, K., \& Kjørholt, E. S. (2008). Barnekonvensjonen : barns rettigheter $i$ Norge. Oslo: Universitetsforlaget.

Johansson, E. (2015). Verdipedagogikk i barnehagen. Oslo: Universitetsforlaget.

Korczak, J. (2016). Barnets rett til respekt. Oslo: Cappelen Damm Akademisk.

Kunnskapsdepartementet. (2007). Ot.prp. nr. 47 Om lov om endringer i barnehageloven.

Kunnskapsdepartementet. (2011). Forskrift om rammeplan for barnehagens innhold og oppgaver: med endringer pr. 10. januar 2011. Oslo: Kunnskapsdepartementet.

Kunnskapsdepartementet. (2016). Tid for lek og laring: Bedre innhold i barnehagen (Meld. St. 19 (2015-2016)). Hentet fra http:// www.regjeringen.no.

Köhler-Olsen, J. (2012). Barnets rett til selvbestemmelse $i$ forhold til religiøse normer. (nr. 51), Det juridiske fakultet, Universitetet i Oslo, Oslo.
Lindskov, A. (2005, 23. juni). Den pædagogiske centrifuge. Asteriks, nr. 23.

Lund, I., Godtfredsen, M., Helgeland, A., Nome, D. Ø., Kovac, B. V., \& Cameron, D. L. (2015). Hele barnet, hele løpet; mobbing $i$ barnehagen. Kai Hansens trykkeri: Foreldreutvalgene for barnehager (FUB), grunnopplæringen (FUG) og Sørlandet Sykehus, avdeling for barn og unges psykiske helse (A-Bup), Universitetet i Agder og Kristiansand kommune.

Løgstrup, K. E. (1996). Etiske begreber og problemer. København: Gyldendal.

Melvold, L., \& Øverenget, E. (2015). Profesjon \& kjerlighet : en bok om de yngste barna i barnehagen. Oslo: Kommuneforlaget.

Oettingen, A. v. (2001). Det predagogiske paradoks: et grundstudie $i$ almen predagogik. Århus: Klim.

Palludan, C. (2005). Børnehaven gør en forskel. København: Danmarks Pædagogiske Universitets Forlag.

Thoresen, I. T. (2003). Samfunnets lim. Nytt Norsk Tidsskrift, 1, 104-110.

Thoresen, I. T., \& Winje, G. (2013). Religioner, mangfold og etikk $i$ barnehagen. Oslo: Cappelen Damm Akademisk.

Vase Frandsen, H. (2008). Pcedagogiske verdier \& religion. København: Danmarks pædagogiske universitetsforlag.

Østrem, S., Tholin, K. R., Nordtømme, S., Jansen, T. T., Hogsnes, H. D., Føsker, L. I. R., \& Bjar, H. A. Ø. S. (2009). Alle teller mer: en evaluering av hvordan Rammeplan for barnehagens innhold og oppgaver blir innført, brukt og erfart. Tønsberg: Høgskolen i Vestfold. 